\title{
PEMANFAATAN SERAT POHON PISANG SEBAGAI SERAT PENGUAT MATERIAL KOMPOSIT DI PESANTREN DARUL ISLAH DUSUN IRENG LAUK
}

\section{Utilization of Banana Tree Fiber for Compocite Material Reinforced at Darul Islah Boarding School Ireng Lauk Village}

\author{
Sujita Darmo*, Ida Bagus Alit, I Wayan Joniarta \\ Jurusan Teknik Mesin Universitas Mataram \\ Jalan Majapahit, Nomor 62, Kota Mataram, Provinsi NTB, 83115 \\ ${ }^{*}$ Alamat korespondensi : sujita@unram.ac.id
}

(Tanggal Submission: 12 Mei 2020, Tanggal Accepted: 28 Agustus 2020)

\begin{abstract}
ABSTRAK
Sumberdaya alam lautan di daerah Provinsi Nusa Tenggara Barat masih belum dioptimalkan dengan baik. Kegiatan produksi ikan dari kegiatan penangkapan oleh para nelayan masih baru mencapai angka $10 \%$ dari total potensi yang ada (Dinas Kelautan dan Perikanan NTB, 2015). Salah satu penyebabnya adalah karena adanya keterbatasan pada permodalan dan peralatan, seperti perahu. Mahalnya harga perahu nelayan dari bahan fiberglass ini bisa bisa ditekan dengan menggunakan fiber/serat alaternatif yang berasal dari alam, seperti serat pohon pisang hijau. Kegiatan pengabdian kepada masyarakat ini bertujuan untuk memberikan ketrampilan kepada para santri tentang pembuatan serat/fiber dari pohon pisang hijau dan penggunaanya dalam pembuatan perahu dari bahan fiber glass. Metode kegiatan pengabdian kepada masyarakat ini berupa penyuluhan tentang pembuatan serat dari pohon pisang hijau dengan melibatkan mahasiswa Unram yang sedang melaksanakan kegiatan KKN Tematik. Secara umum kegiatan penyuluhan berjalan sesuai dengan jadual, meskipun ada dalam penyelesaian peralatan, karena kendala dana. Berdasarkan hasil evaluasi para satri dan masyarakat sekitar Pesantren Darul Islah sudah bisa membuat fiber dari pohon pisang. Sehingga dapat meningkatkan nilai ekonomi pohon pisang hijau, semula dianggap sampah dapat dimanfaatkan dan dijual dalam bentu serat/fiber untuk penguat material komposit, sebagai bahan pembuat perahu nelayan. Kesimpulannya kegiatan pengabdian yang telah dilakukan dapatmeningkatkan kemampuan dan ketrampilan para santri untuk mengaplikasikan serat pohon pisang hijau sebagai serat penguat material komposit untuk bahan pembuatan perahu fiberglas.
\end{abstract}

Kata kunci: material komposit, fiber glass, serat pohon pisang hijau.

\section{PENDAHULUAN}

Sumber daya alam kawasan laut daerah Nusa Tenggara Barat sangat potensial. Luas perairan laut $174.378 \mathrm{Km} 2$, dengan potensi perikanan tangkap 428.439 ton/tahun (Bappeda NTB, 2012). Produksi ikan yang bisa ditangkap oleh para nelayan belum optimal baru mencapai $10 \%$ (Dinas Kelautan dan Perikanan NTB, 2015). Penyebabnya adalah keterbatasan modal dan 
peralatan. Hanya sekitar $20 \%$ dari nelayan yang memakai perahu sederhana dengan motor tempel. Perahu yang dipakai biasanya berbahan kayu dan fiberglass. Kedua jenis perahu tersebut harganya mahal, harganya berkisar 125 juta sampai 200 juta. Hal ini disebabkan oleh semakin langkanya bahan baku, yaitu kayu waru dan harga fiberglass yang tinggi karena harus mendatangkan dari Jawa. Kondisi berakibat pada kurangnya industri perahu dan minimnya kapasitas produksi.

Mahalnya harga perahu nelayan dari bahan fiber glass ini bias bias ditekan dengan menggunakan fiber/serat alaternatif yang berasal dari alam, seperti serat pohon pisang hijau. Pisang hijau merupakan komoditas andalan propinsi NTB dari sector perkebunan. Luas areal pisang hijau di NTB saat ini sudah mencapai $2.500 \mathrm{Ha}$ (Erawati, 2015, Dinas Perkebunan NTB). Dari hasil analisa yang dilakukan, pendapatan dari usahatani pisang yang diusahakan dalam kebun monokultur dapat mencapai Rp 28 juta/ha/ tahun atau rata-rata Rp 2,3 juta/bulan, itu bisa lebih jika ada usaha untuk memanfaatkan pohonnya menjadi serat alternatif.Berdasarkan hasil peneltian S.M. Salit, 2014, kekuatan material komposit dengan serat pohon pisang mencapai 44 - $50 \mathrm{Mpa}$. (15\% dibawah kekuatan tari dari material fiberglass). Lebih lanjut serat pohon pisang hijau bisa diaplikasikan sebagai serat penguat pada material komposit, untuk aplikasi peralatn rumah tangga, (Supada A., dkk, 2014), dan juga bisa diaplikasikan pada pembuatan papan paartikel, (Purwanto D., dkk, 2016), sebagai pengganti pengganti partikel kayu, dalam rangka menanggulangi kerusakan hutan (Priyono, 2016). Berdasarkan hasil penelitian (Sujita, dkk, 2014) Sifat mekanik komposit hybrid laminat fiberglass-serat batang pisang hijau, mendekati papan partikel, dan tidak menyerap air (Sujita, dkk, 2015).

Pesantren Darul Islah adalah salah satu lembaga pendidikan Islam yang sebagian besar orang tua atau wali santrinya adala nelayan, petani, pemandu wisata dan karyawan Industri pembuatan perahau dari bahan fiber glass yang ada di dekat Dusun Ireng Lauk. Jumlah industri pembuatan perahu nelayan dari bahan fiberglass ada tiga industri. Sekitar lokasi pesantren adalah areal pesawahan dan perkebunan pisang hijau dan kelapa. Limbah dari hasil perkebunan tersebut, terutama pohon pisang belum dimanfaatkan secara maksimal, hanya untuk pakan ternak itupun hanya pohon pisang hijau yang bagian dalam.

Kondisi diatas merupakan peluang dan tantangan bagi warga khalayak sasaran (Warga Pesantren Darul Islah dan masyarakat dusun Ireng Lauk) untuk mengolah pohon pisang menjadi serat, bisa dijual ke industri pembuatan perahu dari bahan fiberglass, sebagai penguat komposit. Selain Bidang industri pembuatan perahu fiberglass dengan memanfaatkan serat pohon pisang hijau sebagai fiber/serat alternatifnya, merupakan peluang usaha baru dalam rangka mengurangi pengangguran dan meningkatkan kesejateraan masyarakat sekitar Pesantren Darul Islah. Alasannya ketersediaan sumber daya alam berupa pohon pisang hijau sebagai bahan serat sangat melimpah, proses pembuatannya mudah, mempunyai sifat mekanik yang layak dijadikan sebagai bahan fiber untuk standart material komposit.

Kegiatan pengabdian masyarakat yang dilakukan bertujuan memberikan wawasa atau mengedukasi warga Pesantren Darul Islah Dusun Ireng lauk, agar bisa memanfaatkan pohon pisang hijau menjadi serat, sehingga bisa meningkatkan nilai ekonomi dari pohon pisang hijau yang selama ini hanya sebagai sampah, dengn penyuluhan di lapangan. Sehingga bisa, meningkatkan kemampuan dan ketrampilan para santri untuk mengaplikasikan rekayasa serat pohon pisang hijau sebagai serat penguat. Seperti pada pembuatan perahu, meningkatkan pengetahuan wirausaha dan menambah pengalaman berwirausaha dibidang pembuatan material komposit, menciptakan keterkaitan dan kesepadanan antara 
Perguruan Tinggi dengan lembaga pendidikan nonforma (pondok pesantren).

\section{METODE KEGIATAN}

Kegiatan pengabdian kepada masyarakat ini melibatkan mahasiswa UNRAM yang tengah melaksanakan kegiatan KKN Tematik di Desa Jatisela yang berjumlah 5 orang, almuni Jurusan Teknik Mesin satu orang. Kegiatan ini berlokasi di Pondok Pesantren Darul Islah Dusun Ireng Lauq Desa Jaisela Kecamatan Gunungsari Kabupaten Lombok Barat dengan menjadikan masyarakat sekitar dan para santri di Pondok Pesantren tersebut sebagai sasarannya. Alat dan bahan yang digunakan berupa alat penyerut serat, cetakan material komposit, penekan, pengaduk,kuas, gunting, baskom, sarung tangan, masker, sedangkan bahan yang digunakan meliputi pohon pisang hijau (puntiq saba), polyester, katalisdan peluma.

Pelaksanaan kegiatan pengabdian ini dilaksanakan dalam beberapa tahapan. Adapun tahapan kegiatan sebagai berikut :

\section{Survei awal}

Survei awal dilakukan untuk mendapatkan data tentang potensi pohon pisang diwilayah sekitar pondok Pesantren Darul Islah. Kegiatan ini dibantu oleh mahasiswa yang sedang melakukan kegiatan KKN di desa tersebut.

\section{Penyuluhan}

Dalam kegiatan penyuluhan materi yang disampaikan meliputi:

- Potensi Ekonomi Serat Pohon Pisang

- Pembuatan serat dari pohon pisang

- Mengaplikasikan serat alam (serat pohon pisang), pada pembuatan material komposit

\section{Pendampingan Pelatihan}

Pendampingan pelatihan merupakan bentukkegiatan praktek dari teori yang telah diberikan sebelumnya pada kegiatan penyuluhan. Pendampingan pelatihan disini dilakukan mulai dari penggunaan bahan baku berupa pohon pisang hijau hingga diolah menjadi serat dan memanfaatkan serat tersebut sebagai penguat material komposit fiberglass untuk aplikasi dibidang perlatan rumah tangga, bahan bangunan dan konstruksi perahu nelayan. Pendampingan pelatihan pembuatan material komposit dengan serat penguat serat pohon pisang hijau diperlukan agar kegiatan dapat berjalan dengan lancer dan dapat memotivasi para santri, kelompok/masyarakat petani dan nelayan supaya dapat memanfaatkan potensi limbah yang ada menjadi produk yang bernilai ekonomi lebih tinggi.

\section{Evaluasi}

Tahap akhir darikegiatan ini adalah dengan melakukan evaluasi. Evaluasi dilakukan untuk mengetahui kemampuan dan keberhasilan khalayak sasaran dalam menyerap materi dan melakukan praktek pengolahan limbah pohon pisang hijau menjadi serat untuk diaplikasikan sebagai penguat pada material komposit.

\section{HASIL DAN PEMBAHASAN}

\begin{tabular}{cll}
\multicolumn{2}{c}{ Sebelum kegiatan } & pengabdian \\
dilaksanakan, tim pengabdian & melakukan
\end{tabular}
persiapan terlebih dahulu agar kegiatan dapat berjalan dengan lancar. Persiapan yang dilakukan mulai dari melakukan survey untuk dapat melakukan koordinasi dengan kepala desa dalam hal menentukan dan menyepakati jadwal penyuluhan di lokasi tersebut sesuai dengan kondisi peserta. Persiapan selanjutnya yaitu menyiapkan materi untuk penyuluhan dan pelatihan, serta menyiapkan alat dan bahan yang dibutuhkan untuk pelatihan pembuatan material komposit. Kegiatan pengabdian di Pondok Pesantren Darul Islah Dusun Ireng Lauq ini juga melibatkan mahasiswa yang sedang menjalankan KKN tematik di desa tersebut sebagai salah satu tugas mata kuliah Material Komposit yang harus dipenuhi oleh mahasiswa Jurusan Teknik Mesin Unram. Kegiatan pengabdian dilaksanakan di Pondok Pesantren Darul Islah Dusun Ireng Lauq, 
Desa Jatisela, Kecamatan Gunungsari, Kabupaten Lombok Barat yang dihadiri oleh kepala Desa Jatisela, Para Pengurus Pondok Pesantren, Para santri, serta warga sekitar yang sebagaian besar para petani, nelayan, tukang ojek dan pemandu wisata.

Kegiatan diawali dengan acara sambutan dari kepala Desa setempat yang kemudian disusul dengan penyampaian materi penyuluhan oleh tim pengabdian, praktek pembuatan serat pohon pisang hijau, praktek pembuatan material komposit dengan serata penguat serat pohon pisang hijau, aplikasi material komposit diskusi, dan yang terakhir penutupan. Dengan pemaparan materi ini majadikan khalayak mendapatkan yangluas untuk dapat memanfaatkan limbah pohon pisang hijau tersebut manjadi produk baru yang memiliki manfaat ekonomi lebih tinggi.

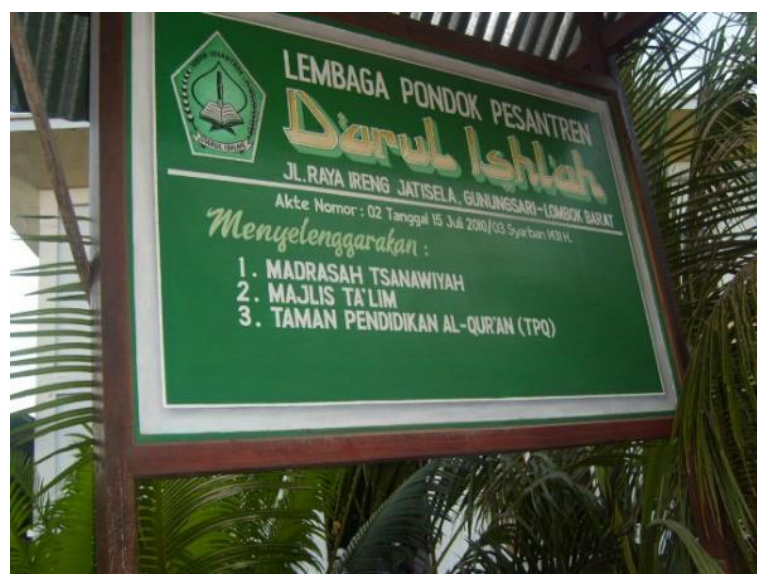

Gambar 1. Tempat Kegiatan Penyuluhan

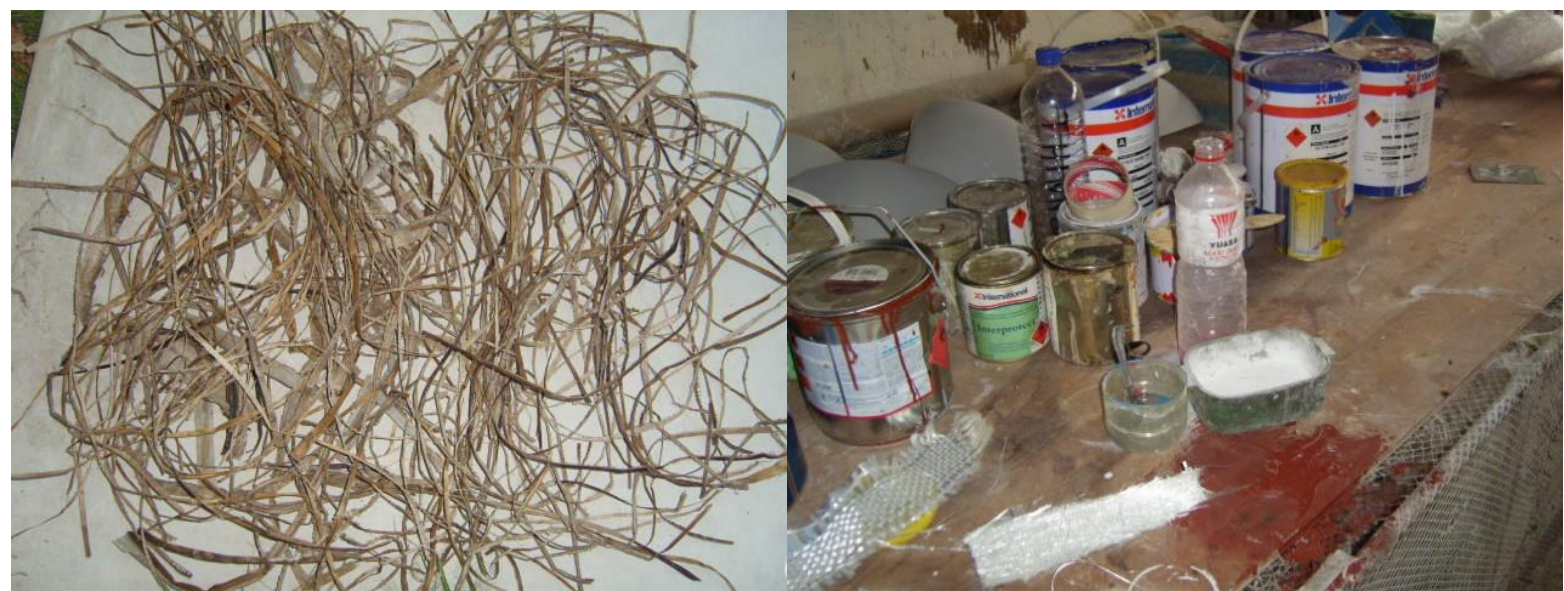

Gambar 2. Serat Pohon Pisang, Resin polyester dan Katalis (Serat pohon pisang sebagai penguat, resin polyester sebagai matrik, katalis agar mempermudah ikatan antar partikel serat)

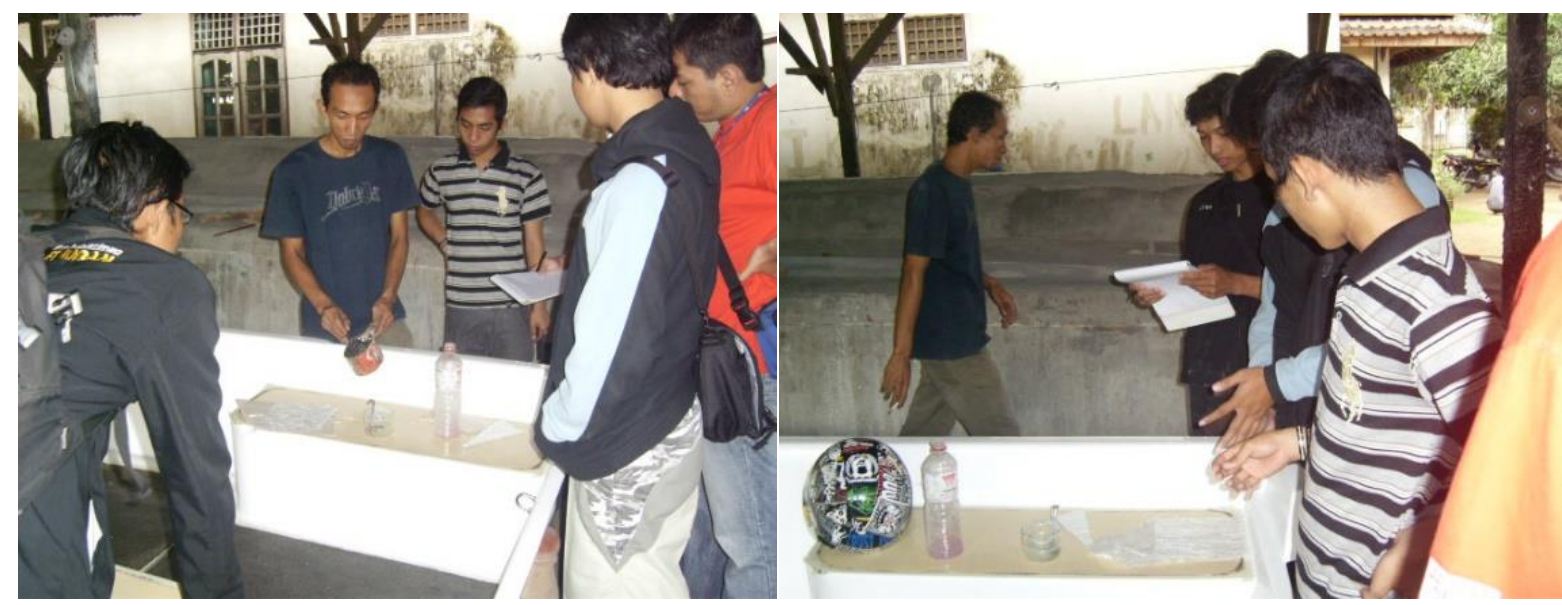

Gambar 3. Persiapan dan Tata Cara Aplikasi Serat Pohon Hijau Sebagai Serat Pada Pembuatan Perahu 


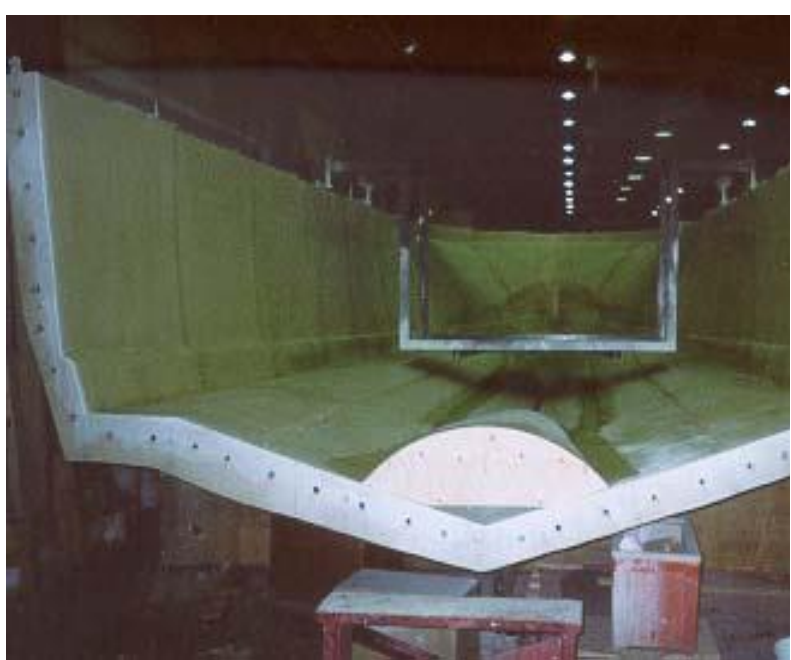

Gambar 4. Bagian perahu yang terbuat dari Fiber glass dengan serat penguat dari pohon pisang hijau

\section{Aplikasi Material Komposit Pada Pembuatan Perahu}

Secara umum kegiatan penyuluhan berjalan sesuai dengan jadual, meskipun ada keterlambatan dalam penyelesaian peralatan, karena kendala dana. jumlah peserta yang hadir saat sosialisasi mencapai 20 orang, 15 orang dari pemuka pesantren Darul Islah, 5 orang dari dusun lain tapi masih termasuk wilayah kecamatan Gunungsari dari 20 orang 2 orang adalah pengusaha/pemilik industri pembuatan perahu fiberglass. Sedangkan yang lain adalah para pemuda yang belum mempunyai pekerjaan tetap, biasa bekerja sebagai tukang ojek dan tukang kebun

\section{A. Faktor Penghambat}

Pelaksanaan kegiatan pengabdian tidak luput dari rintangan-rintangan yang nenghambat kegiatan selama program berlangsung :

- Kurangnya penguasaan Bahasa Sasak oleh para tim pelaksana sehingga bias menghambat komunikasi.
- Bersamaan dengan datangnya bulan Dzulhijah (bulan haji), kegiatan agak tergangggu.

- Saat berlangsungnya kegiatan , musim hujan, sehingga agak kesulitan dalam menerapkan serat alam (serat pohon pisang hijau), pada pembuatan material komposit.

\section{B. FaktorPendorong}

Faktor yang mendorong sehingga kegiatan pelaksanaan penyuluhan ini berhasil sesuai indicator pencapaian tujuan adalah :

- Para pengusaha pembuatan perahu fiberglass sudah lama menginginkan bantuan teknologi untuk menekan ongkos produksi dengan menggunakan serat penguat alternative selain fiberglass

- Sebagian besar peserta sosialisai adalah para pemuda yang masih menganggur, mereka berharap dengan kegiatan ini bias membuka lapangan kerja baru.

- Adanya dukungan dari tokoh agama (Tuan Guru) pemuka pesantren Darul Islah dan tokoh masyarakat (Keliang) saat pelaksanaan kegiatan.

- Adanya dukungan dari anggota BPD (Badan Perwakilan Desa) untuk memberdayakan potensi masyarakat desa.

\section{Evaluasi Terhadap Kemajuan Dari Program . \\ Rancangan evaluasi dilakukan tiga kali} selama satu tahun setelah program berakhir. Evaluasi pertama dilakukan dua bulan terakhir setelah program selesai. Evaluasi kedua setelah enam bulan dan evaluasi yang terakhir setelah satu tahun program berakhir. Evaluasi yang dilakukan meliputi, kekuatan material komposit dengan serat pohon pisang hijau, jumlah pemakai material komposit dengan serat pohon pisang hijau pada pembuatan perahu fiberglass, peningkatan pendapatan khlayaksasaran dan jumlah wirausaha baru pembuatan perahu fiberglass. 


\section{KESIMPULAN DAN SARAN}

\section{Kesimpulan}

Kegiatan penyuluhan berupa penerapan serat pohon pisang hijau sebagai penguat material komposit secara umum sangat bermanfaat, dapatmeningkatkan kemampuan dan ketrampilan para santriPesantren Darul Islah Dusun Ireng untuk mengaplikasikan rekayasa serat pohon pisang hijau sebagai serat penguat. Seperti pada pembuatan perahu. Meningkatkan pengetahuan wirausaha dan menambah pengalaman berwirausaha dibidang pembuatan material komposit. Menciptakan keterkaitan dan kesepadanan antara Perguruan Tinggi dengan lembaga pendidikan nonforma (pondok pesantren).

\section{Saran}

Agar hasil dari kegiatan ini lebih berhasil hendaknya, para peserta penyuluhan dilibatkan dalam kegiatan Pameran Teknologi Tepat Guna, untuk lebih mensosialisasikan rekayasa serat pohon pisang hijau sebagai serat penguat. Penguasaan Bahasa Sasak bagi Tim Pelaksana perlu ditingkatkan sehingga tidak mengalami kesulitan dalam komunikasi. Selanjutnya kegiatan jangan dilaksanakan dalam bulan Idhul Adha, karena adat di Pulau Lombok pada bulan tersebut sangat sibuk menyiapkan penyambutan keberangkatan Jamaah Calon Haji.

\section{UCAPAN TERIMA KASIH}

Tim Pengabdian Kepada Masyarakat mengucapkan terimakasih kepada pihak yang terlibat dari kepala desa Jatisela, wakil kepala
Dusun Ireng Lauk, pimpinan Pondok Pesantren Islah dan para santri peserta yang hadir dalam kegiatan pengabdian sehingga kegiatan dapat terselenggara dengan baik.

\section{DAFTAR PUSTAKA}

Erawati, 2015, Data Dinas Perkebunan NTB, Dinas Perkebunan NTB.

Priyono, 2016, Komitmen Berbagai Pihak Dalam Menanggulangi Kerusakan Hasil Hutan, Konggres Kehutanan III, Jakarta, .

Purwanto D., Samet, Mahfus, Sakiman, 2016, Pemanfaatan Limbah Industri Pertanian Untuk Papan Partikel Buatan Secara Laminasi , Balitbang Departemen Perindustrian, Banjar Baru.

S.M. Salit, 2014, Karakteristik Material Polimer Matrik Komposit Diperkuat Serat Pohon Pisang, Pusat Riset UPM Malaysia.

Sujita, Nasmi Herlinasari, 2014., Karakterisasi Sifat Mekanik Komposit Hybrid Laminat Fiberglass-Serat Batang Pisang Hijau, Jurnal Litbangyasa Kebijakan Publik REFORMA, Badan Lingkungan Hidup dan Penelitian (BLHP-NTB), Vol.1/No.2,hal 25-29

Sujita, Sugiman, Nasmi Herlinasari , 2015., Anlisis Uji Penyerapan Air dan Struktur Mikro Komposit Laminate Hybrid Fiberglass dan Batang Pisang dengan Matrx Epoxy, JURNAL PENELITIAN INTEK (Informasi Teknologi) Politeknik Negeri Ujung Pandang, Vol. 2 No.1, hal 35-39

Supada .A., Yudiyanto, Suyono, Aniyati. D., 2012, Alternatif Pemanfaatan Pohon Pisang, Laporan Kegiatan IbM LPPM UNS, Solo. 